DOI https://doi.org/10.32841/2409-1154.2021.47-1.19

\author{
Zhyhadlo O. Yu., \\ orcid.org/0000-0002-1605-7242 \\ Candidate of Philological Sciences, \\ Associate Professor at Foreign Languages Department \\ Institute of Law of Taras Shevchenko National University of Kyiv
}

\title{
FORENSIC LINGUISTICS: HISTORY, MAIN TASKS AND PROSPECTS
}

Summary. The article focuses on the analysis of the value of Forensic Linguistics for the issues of law enforcement and private dispute resolution in common law countries and Ukraine. The aim of the article is to study the scope of tasks in the field of law which can be performed using methods and techniques of contemporary linguistics and to outline the prospects of Forensic Linguistics as an independent field of study.

The paper provides an overview of the definitions of Forensic Linguistics outlining its areas of application and the subject matter. Two major approaches to the tasks of Forensic Linguistics have been described by the author. One of the definitions limits forensic linguistic analysis to the examination of linguistic evidence such as written or recorded messages, to be used in court proceedings. The other implies a broader interpretation of the issues a forensic linguist may deal with and comprises any use of language in a legal context from legislation texts to interaction of legal professionals with suspects and witnesses. The article also dwells upon the history of emergence and development of Forensic Linguistics as a branch of Applied Linguistics in Great Britain and the United States and touches upon the most significant findings of prominent scholars in the field of Forensic Linguistics, particularly in such areas as authorship identification, statute drafting and interpretation and Forensic Phonetics.

It is maintained that the scope of tasks of a forensic linguist with regard to the forensic linguistic evidence analysis as well as its admissibility in court differs depending on jurisdiction. In Ukraine the practical application of Forensic Linguistics is referred to as forensic linguistic expertise which stemmed from authorship analysis, but is gradually expanding its sphere of use to include the issues of national security, protection of non-property rights of an individual, intellectual property rights protection. The author opines that it is vital to explore the findings of forensic linguists from different countries to expand the scope of legal issues to be resolved by linguistic methods, enhance the methodology of Ukrainian forensic linguistic expertise and foster international cooperation in the field of Forensic Linguistics.

Key words: Applied Linguistics, forensic linguistic evidence analysis, Forensic Phonetics, Forensic Sciences, forensic linguistic expertise, expert opinion, authorship identification.

Introduction. Forensic Linguistics as a separate area of Applied Linguistics is one of the disciplines within Forensic Sciences. It has been rapidly developing as a science whose purpose is to bridge the gap between linguistics and law enforcement to serve the purposes of justice and to facilitate establishing the truth in judicial processes. Forensic Linguistics is commonly defined as an application of linguistic knowledge and methods to various legal issues as part of legal proceedings or private disputes which may potentially result in legal action [1, p. 94]. This definition seems to be quite specific as it focuses on "language as a contested object of legal examination" [2, p. 4]. Materials for analysis by a linguist may be valid as evidence in court and vary from written messages, such as ransom notes, mobile phone text messages, suicide notes as well as recorded voice messages in criminal cases to contracts, wills and warning labels in civil cases.

However, alongside with procedural use of linguistic evidence, in its broadest sense Forensic Linguistics studies any use of language in a legal setting [3] including the language of legislation, crosscultural and bilingual communication, interaction of legal professionals with laypeople in and outside the courtroom.

In Ukrainian scholarly literature the term "Legal Linguistics" is used to refer to the area of studies which investigates legal language and communication. Legal Linguistics is defined as an interdisciplinary science which deals with the language of legal theory and practice [4, p. 32]. The tasks of Legal Linguistics include the issues of the language of legislation, authorship of written documents, the analysis of recorded speech and other products of communication, specifics of courtroom discourse, which correlates with the wider interpretation of the tasks of Forensic Linguistics by some prominent western scholars [5].

The outcome or the result of a forensic linguist's analysis of linguistic data is called forensic linguistic evidence analysis in Anglo-Saxon scholarly tradition and forensic linguistic expertise in Ukraine. It seems to be simultaneously the product of the work of a linguist and a specific text genre [6, p. 20]. Despite the growing significance of forensic linguistic evidence analysis in some countries, its scientific and legal status in others is yet to be established. In common law countries, e.g. Great Britain, the United States, Australia, forensic linguists may be called in to provide expert opinion or assistance at different stages of a legal proceeding on quite a regular basis. A linguist can assist law enforcement officers in gathering information at the investigative stage or may be summoned to give an opinion at the trial stage or the appeal stage. In Ukraine, however, practical application of linguistic methods to the analysis of linguistic evidence in the form of forensic linguistic expertise has not acquired the legal status of an independent type of expertise being applied within the scope of forensic expertise.

As the range of problems which Forensic Linguistics tackles nowadays reaches far beyond the issues of legal proceedings, there is a need to analyse its current tasks and specify the prospects of this area of science as a common ground for the studies of law and linguistics which accounts for the relevance and the practical value of this research both for linguists and legal professionals. The purpose of the article is to give an overview of the scope of tasks 
in the field of law, language and communication which are resolved with the help of the methods and approaches offered by Forensic Linguistics and to delineate the prospects for its development.

Discussion. The analysis of the current tasks of this area of Applied Linguistics is hardly possible without the outline of the history of its emergence and development. The term "Forensic Linguistics" was coined in the 1960s by a Swedish linguist J. Svartvik who used the method of corpus analysis to study the statements of the accused in a murder case. M. Coulthard argues that it was J. Svartvik's analysis in the field of authorship attribution that marked "the birth of a new discipline" $[5, \mathrm{p} .15]$. Thus in the second half of the $20^{\text {th }}$ century in English speaking countries linguistic methods started to be used for authorship identification and securing suspects' rights before and during interrogation.

The development of Forensic Linguistics in the United Kingdom pertains to the specific manner of recording of witnesses' statements in the process of interrogation which existed in England for a long period of time [3]. Referred to as Judges' Rules, they prescribed that witnesses' and suspects' statements were to be dictated to and recorded verbatim by a police officer without interruptions for questions, which proved to be practically unworkable. Since very few people managed to deliver their stories in the required fashion, police officers approached this task in their own way, making questions and taking down the statements of the suspects and then typing them not in the words of the suspect, but in their own words. This fact made the issue of authorship attribution rather questionable. Due to the involvement of linguistic analysis of incriminating statements in the second half of the twentieth century which contributed to proving that their authorship could hardly be authentic, some of the convicts were posthumously pardoned. J. Svartvik and M. Coulthard were the first linguists to have contributed to the progress of Forensic Linguistics in the UK.

Another powerful driving force which stimulated the development of Forensic Linguistics originates from the peculiarities of legal language which is often referred to as legalese. Legal English, with vast borrowings from Latin and French, is characterized by complex syntax, insufficient punctuation, foreign phrases, Latin words, unusual pronouns and set phrases, archaisms and technical terms [7, p. 2-3]. These features make it difficult for a lay person to understand legal English. Being highly formulaic on the one hand, it differs enormously both in lexis and grammar from plain English thus putting a non-specialist at a disadvantage as special interpretative skills are called for. Whether it concerns misunderstanding of Miranda Warnings by an arrestee or misinterpretation of an indictment at a court hearing, it proved to violate the rights of an individual.

In the USA as well as in other English speaking jurisdictions not only does a person accused of a crime have the right to remain silent, but also the right to be told about their right to silence, so to say they need not speak unless they want to, as everything they say may be used against them in court. This is called the Miranda Warning in the USA and the Police Caution in the UK and Australia. Police officers are obliged to recite this information to the arrestee before questioning. However, as some forensic linguists point out, the language of these texts is rather obscure and unintelligible for laypeople [5]. As a result, the efforts of forensic linguists is focused on the revision of the text of the Caution to improve its intelligibility and to make sure that any individual actually understands its meaning to be able to enjoy their constitutional right to keep silent.
Due to the efforts of R. Shuy and other US linguists, who have analyzed a vast bulk of texts in civil and criminal law and have not taken "even the 'simplest' word or concept for granted" [3] as far as their understandability is concerned, the text of the Miranda warning has been simplified. Moreover, a detainee may be asked to sign a statement acknowledging their understanding of the aforesaid and a police officer reciting the Miranda rights to the suspect may ask them: "Do you understand?" after each phrase to ensure understanding of the Mirandized person.

In the UK, however, the improved version of the police caution issued in 1995 as part of changes under the Criminal Justice and Public Order Act and reduced from 60 words to 37 "to gain in clarity" has not changed the situation with understanding for the better. As the study of a forensic psychologist revealed, 42 per cent of A-level pupils had a difficulty with understanding the new text of the caution which is: "You do not have to say anything. But it may harm your defense if you do not mention when questioned something which you later rely on in court. Anything you do say may be given in evidence" [8] since now it sounds even more confusing and ambiguous.

Intellectual property claims is yet another area where application of the methods of Forensic Linguistics proved to be invaluable. Authorship authenticity and the status of trademarks as proper names and morphological and lexical units have been the subject of research for forensic linguists since the earlier part of the twentieth century. Diverse approaches to this issue including average word and sentence length, lexical richness used to be applied.

Forensic Phonetics or Speech Forensics is an area within Forensic Linguistics which deals with the analysis of speech to be used as evidence in court. Being fast-tracked by the development of acoustic engineering, Forensic Phonetics is concerned with the issues of speaker identification, authentication of recordings, decoding spoken messages, analysis of different behavioral states of an individual, including stress, intoxication, illness or deception $[9$, p. 27].

In Ukraine Forensic Linguistics or Legal Linguistics explores a variety of subjects ranging from lexical, stylistic and pragmatic features of legal discourse and its subtypes to the history of the language of law. Alongside with the theoretical issues, it tackles practical tasks which include the performance of forensic linguistic expertise to be used in crime investigation and in court.

Forensic linguistic expertise is a type of forensic expertise which may be appointed in accordance with the Instructions on the Appointment and Conduct of Forensic Expertise and Expert Analysis issued by the Ministry of Justice of Ukraine in 1998. The subject matter of forensic linguistic expertise is oral or written speech which may be live or recorded. The scope of tasks forensic linguistic expertise is applicable to includes the analysis of proper names, slogans, texts of advertisements, company names in order to establish similarity; identification of emotional colouring of texts and the degree of their impact on the addressee; resolving problems stemming from multiple interpretations of legal texts when different interpretations may result in different legal ramifications; evaluation of discourse in light of the existing speech norms and principles [10]. Forensic linguistic evidence analysis employs an array of linguistic methods including synonymic transformation, syntactic analysis, vocabulary analysis, pragmatic analysis, methodology of the Speech Act theory, discourse analysis and others [6, p. 22-23]. 
With regard to the tasks forensic linguistic expertise is expected to perform as well as the types of data it deals with, there are three major types of forensic linguistic expertise: general, detailed and enhanced expertise [11, p. 155]. General forensic linguistic expertise aims at analyzing the degree of the text's correspondence to the existing norms of the language and providing relevant corrections. Detailed forensic linguistic expertise is applied when it is necessary to avoid multiple interpretations of a legal document, for instance, in the text of a contract or in the translation of legislation. Enhanced forensic linguistic expertise may be called for in cases of disputes caused by a specific use of words in a specific context.

Another typology of forensic linguistic expertise has been offered by the Ukrainian Bureau of Forensic Linguistic Expertise of the National Academy of Sciences of Ukraine. It includes the following major types of forensic linguistic analysis [12, p. 15]: 1) expert examination of the disputed legal documents; 2) expert examination in the cases of protection of dignity and reputation of an individual or a business; 3) expert examination in the cases of violence, national security, stirring up interethnic hostility; 4) expert examination in the cases of threats, blackmail and extortion; 5) expert examination in the cases of fraud; 6) expert examination of the documentary records of proper names; 7) expert examination in the cases of registered trademark protection.

In addition to the application of forensic linguistic expertise to the analysis of legislation texts or the data used as evidence in court, the range of task of Forensic Linguistics in Ukraine may be expanded to resolve the problems of authorship identification of texts as cultural phenomena, the impact of texts on social norms and values of the society, and expert analysis of the effectiveness of advertising texts and user manuals [13, p. 222-223]. Another challenging topic to be tackled by researchers within the domain of Forensic Linguistics is the analysis of the communicative and pragmatic features of the interaction of legal professionals, law enforcement officers with laypeople during interrogations. Such studies may result in the improved procedures of an investigative interview as an enhanced variant of interrogation of victims, witnesses and suspects with the focus on the adherence to human rights, prevention of manipulative behaviour and obtaining more reliable evidence.

Conclusions. Although Forensic Linguistics is a relatively recent area of science, its growing importance is undoubtful both in common law countries and Ukraine. The outcomes of the work of linguists are applied in litigation and for expert analysis of texts of laws. Linguistic evidence may be admissible in court in case it is relevant and meets certain requirements of statutory law. In addition, expertise and research methods of forensic linguists may be invaluable in other areas of social life which only partly overlap with judicial process, such as social, cultural and commercial spheres. With regard to the obvious value of contribution of Forensic Linguistics to the legal forum, the prospects of future investigation are viewed in studying the international experience of forensic linguists as it may help to enhance methods of Ukrainian forensic linguistic experts, make them more rigorous and reliable to serve the purposes of linguistic evidence expertise in civil and criminal cases. Furthermore, the analysis of the findings in the field of application of linguistic methods to various legal issues can foster the development of Forensic Linguistics as a distinct field of science in Ukraine.

\section{References:}

1. Danielewicz-Betz A. The Role of Forensic Linguistics in Crime Investigation. URL: https://www.academia.edu/3573524.

2. Durant A. Applying Linguistics: Questions of Language and Law. URL: https://eprints.mdx.ac.uk/392/.

3. Olsson J. What is Forensic Linguistics? URL: https://www.thetext.co.uk.

4. Прадід Ю.Ф. Юридична лінгвістика в Україні: здобутки і перспективи. Мовознавство. № 2. 2011. С. 31-37.

5. Coulthard M. Forensic Linguistics: the Application of Language Descriptions in Legal Contexts. Langage et société. № 132. 2010/2. P. 15-33. URL: https://www.cairn.info/revue-langageet-societe-2010-2-page-15.htm.

6. Баранов А.Н. Лингвистика в лингвистической экспертизе (метод и истина). Вестник ВолГУ. Серия 2, Языкознание. Т. 6. № 2. 2017. C. $18-27$.

7. Haigh R. Legal English. London: Routledge-Cavendish, 2009. 330 p.

8. Ward S. New Police Caution Loses 23 Words and Gains in Clarity. URL: https://www.independent.co.uk/news/new-police-caution-loses23-words-and-gains-in-clarity-1570533.html.

9. Hollien H. About Forensic Phonetics. URL: https://revije.ff.uni-lj.si/ linguistica/article/view/603.

10. Рогова М.О., Лепеха Т.В. Види лінгвістичних експертиз. URL: http:/jvestnik-sss.donnu.edu.ua/article/download/4847/4877.

11. Богословська М.О. Деякі аспекти судово-лінгвістичної експертизи. Вісник Академіїадвокатури України. 1 (14). 2009. С. 152-158.

12. Ажнюк Л.В. Лінгвістична експертиза як юридичний інструмент. URL: http://lingvoexpert.org.ua/files/Lesia_Azhniuk_Linhvistychna_ ekspertyza.pdf.

13. Черненко Г.А. Сфери застосування лінгвістичної експертизи. Studia Linguistica. Вип. 6. 2012. С. 220-223.

Жигадло О. Ю. Юридична лінгвістика: історія виникнення, основні завдання та перспективи

Анотація. Стаття присвячена аналізу значення юридичної лінгвістики для сфери правозастосування та врегулювання приватних спорів у країнах загального права та в Україні. Метою статті $\epsilon$ вивчення обсягу завдань у правовій сфері, які можуть бути виконані із застосуванням методів і прийомів сучасної лінгвістики, й окреслення перспектив розвитку юридичної лінгвістики як незалежної галузі знань.

У статті надано визначення юридичної лінгвістики 3 огляду на сфери іiі застосування, завдання та предмет. Проаналізовано два основні підходи до визначення завдань юридичної лінгвістики. Згідно з одним із підходів завдання лінгвістичного аналізу обмежується вивченням фактичних матеріалів, що $є$ продуктом мовленнєвої діяльності людини, таких як письмові повідомлення, аудіо- та відеозаписи, які можна використовувати як доказ під час судового розгляду цивільних або кримінальних справ. Другий підхід передбачає більш широке тлумачення завдань юридичної лінгвістики, що включають будьяке використання мови у правовому контексті - від текстів законів до комунікативної взаємодії юристів із підозрюваними та свідками. У статті описано історію виникнення та розвитку юридичної лінгвістики як окремої галузі прикладної лінгвістики у Великій Британії та США, а також найбільш значущі доробки видатних науковців у галузі юридичної лінгвістики, зокрема в таких сферах, як встановлення авторства, створення та тлумачення законодавчих актів і юридична фонетика.

Встановлено, що обсяг завдань лінгвіста, що аналізує мовні дані для представлення їх як доказів у суді, різниться залежно від юрисдикції. В Україні практичне застосування юридичної лінгвістики називається судово-лінгвістичною 
експертизою, яка здебільшого використовується для встановлення авторства, але поступово розширює сферу своєї діяльності, включаючи питання національної безпеки, захист честі, гідності та ділової репутації особи, захист прав інтелектуальної власності. Наукове дослідження надбань юридичної лінгвістики у зарубіжних країнах є необхідним задля розширення кола юридичної проблематики, що може бути вирішена за допомогою лінгвістичних методів, вдосконалення методології української судоволінгвістичної експертизи та налагодження міжнародного співробітництва в галузі юридичної лінгвістики.

Ключові слова: прикладна лінгвістика, лінгвістична експертиза, судова експертиза, юридична фонетика, авторознавча експертиза, правозастосування. 